\title{
IgA Pemphigus in a Child - a Case Report
}

\author{
Branislav LEKIĆ1, Mirjana GAJIĆ-VELJIĆ1, 2, Svetlana POPADIĆ1, ${ }^{1}$ and Miloš NIKOLIĆ1,2 \\ ${ }^{1}$ Clinic of Dermatovenereology, Clinical Center of Serbia, Belgrade, Republic of Serbia \\ ${ }^{2}$ University of Belgrade, School of Medicine, Belgrade, Republic of Serbia \\ ${ }^{*}$ Correspondence: Prof. Dr. Miloš Nikolić, Department of Dermatovenereology, School of Medicine, \\ University of Belgrade, Pasterova 2, 11000 Belgrade, Serbia, E-mail: milos.nikolic@med.bg.ac.rs
}

UDC 616.527-053.2

\begin{abstract}
IgA pemphigus (IGAP) is a rare autoimmune bullous disease characterized by IgA deposits on keratinocyte cell surfaces. The IGAP is classified into: 1) subcorneal pustular dermatosis (SPD) type, and 2) intraepidermal neutrophilic (IEN) IgA dermatosis type. So far, only 9 children with IGAP have been described in the literature, of whom only 3 with SPD type. We report a 3-year-old boy with SPD type of IGAP. Clinically, he presented with pruritic vesicles, pustules and erosions on the face, trunk, groin area, and extremities. Histopathology showed subcorneal pustules containing a few acantholytic cells. Direct immunofluorescence (DIF) test of Tzanck smear showed intercellular IgA deposits on the surface of the groups of epidermal cells. Oral dapsone and prednisone induced remission after two weeks; the treatment was discontinued 11 months later, and complete remission was achieved during 19 months without any treatment. Direct immunofluorescence of Tzanck smear is a simple, sensitive, rapid and non-aggressive test, very suitable for the diagnosis of IGAP in children.
\end{abstract}

Key words: Immunoglobulin A; Pemphigus; Child, Preschool; Signs and Symptoms; Diagnosis; Cytodiagnosis; Skin Tests; Dapsone; Prednisone; Treatment Outcome

$\lg$ A pemphigus (IGAP) is a rare variant of pemphigus presenting with vesiculopustular skin lesions; histopathologically, IGAP is characterized by neutrophil infiltration and acantholysis in the epidermis (1). Binding of IgA antibodies to keratinocyte cell surface antigens leads to accumulation of neutrophils in the epidermis, resulting in intraepidermal blistering (2). Depending on blister location, two variants of the disease have been recognized: 1) subcorneal pustular dermatosis (SPD) and 2) intraepidermal neutrophilic (IEN) IgA dermatosis (3). The incidence and prevalence of IGAP is not known, but it is certainly very low $(3,4)$. The disease is extremely rare in pediatric age group; up to now, only 9 children have been described in the literature, of whom only 3 with SPD type (5).

\section{Case report}

We present a 3-year-old Caucasian boy, with a 2-month history of pruritic vesicles, pustules and erosions on the face, trunk and extremities. The lesions were first treated as im- petigo with systemic and topical antibiotics, with no improvement. The patient's medical history was unremarkable. On admission, the boy had pustules and erosions covered with crusts, predominantly on the face and trunk (Figure 1). During the following days, numerous vesicles and pustules appeared on erythematous base, mainly over the trunk (Figure 2) and groin area (Figure 3). Nikolsky's sign was negative. The oral mucosa was uninvolved.

Routine laboratory test results were normal. Bacterial cultures from pustules were all negative. Serum IgA autoantibodies to tissue transglutaminase and to endomysium were negative. The cytological (Tzanck) test showed rare acantholytic cells, numerous neutrophils and neutrophils surrounding acantholytic cells ("Sertoli rosette" phenomenon).

Histological examination revealed subcorneal pustules with neutrophils and a few acantholytic cells (Figures 4 and 5).

Direct immunofluorescence (DIF) of perilesional skin and indirect immunofluorescence (IIF) - IgG and IgA - with monkey esophagus tissue were negative. DIF test per- 
formed on Tzanck smear showed intercellular IgA deposition on the surface of segregated groups of epidermal cells (Figure 6). No deposition of other immunoglobulins or complement components was detected.

The boy was treated with oral prednisone at $1 \mathrm{mg} / \mathrm{kg} /$ day with gradual dose tapering over 9 months, in combination with dapsone at $1.6 \mathrm{mg} / \mathrm{kg} /$ day with gradual dose tapering over 11 months, and, before complete epithelization of erosions, with topical antibiotics and corticosteroids. The twoweek therapy resulted in a complete resolution of skin lesions, leaving only residual but transitory pigmented macules. There were no signs of recurrence 19 months after the therapy cessation.

\section{Discussion}

$\lg$ A pemphigus is a rare, neutrophilic, acantholytic skin disorder that usually occurs in middle-aged and elderly persons (approximately 70 cases have been reported in the literature); the average age of onset is 48 years (6). IGAP is an extremely rare condition in children - detailed PubMed search revealed only 9 cases, of whom 3 were classified as SPD type (two girls and one boy), 2 were IEN type (one girl and one boy), one was classified as pemphigus vegetans variant IGAP (one boy) and the other 3 cases were unclassified (three girls) $(5,6,7,8,9$, $10,11,12,13)$. The youngest reported patient was a 1-month-old girl (9).

Patients with both types of IGAP clinically present with flaccid vesicles or pustules, or both, on erythematous or normal skin (14). Patients with the SPD type sometimes show irregular erythematous skin lesions with vesiculopustules, erosions and desquamation resembling the features of subcorneal pusular dermatosis (Sneddon-Wilkinson disease) (15). The IEN type demonstrates a characteristic clinical feature, the so-called "sunflower-like" configuration (16). A herpetiform appearance has also been reported (17). A pemphigus vegetans variant of the IGAP occurring during immunosuppressive drug therapy was described in a 7-year-old boy (10). The sites of predilection are groin, axillae, trunk, proximal extremities and lower part of the abdomen, scalp and postauricular areas $(3,5)$. Mucous

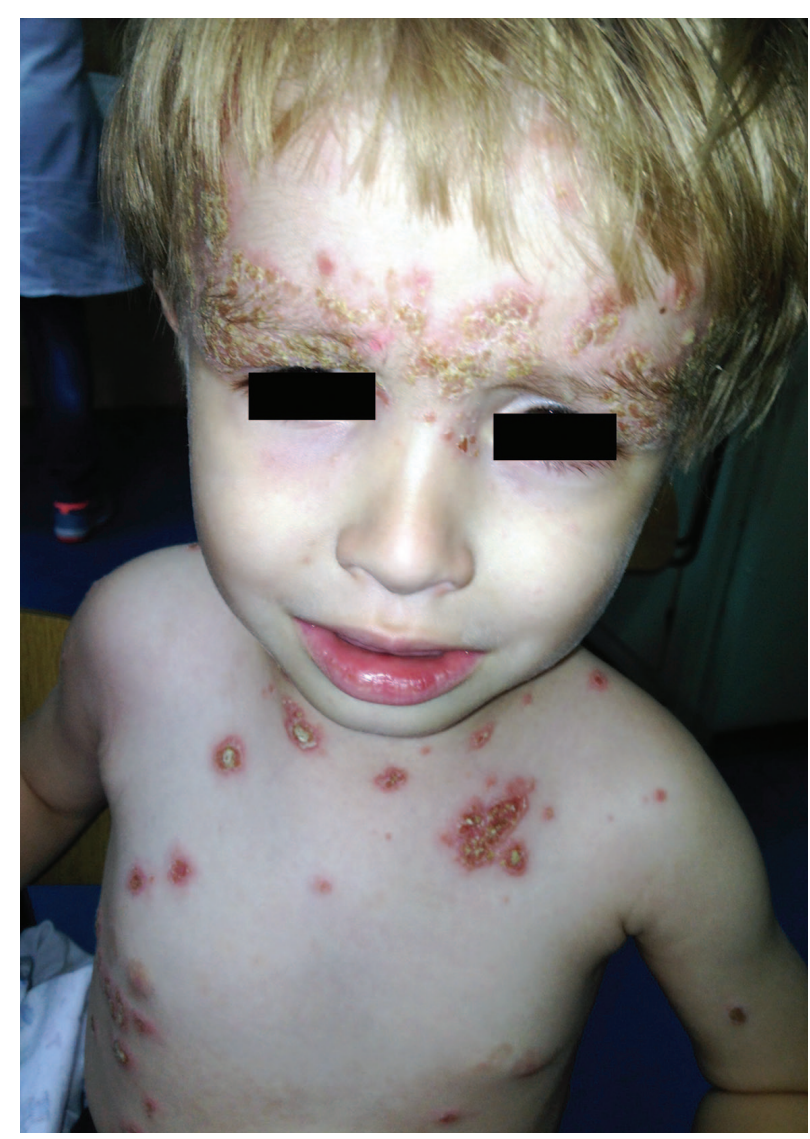

Figure 1. Pustules, superficial erosions, yellow crusts and erythematous plaques on the face and trunk

membranes are rarely involved (3). Teraki et al. reported a 7-year-old girl with lesions involving not only the skin, but also the oral mucosa (13). Pruritus is also a significant symptom that may interfere with the patient's daily activities (18). In children, the main clinical differential diagnosis includes impetigo contagiosa, linear IgA dermatosis, subcorneal pustular dermatosis, and pemphigus foliaceus (7).

In both variants, the blisters contain acantholytic keratinocytes and a variable number of neutrophils (19). Acantholysis in IgA pemphigus is much milder than in classic pemphigus. Characteristically, the clefts and pustules localize in the subcorneal region in SPD type IGAP, whereas they are present in the entire or mid epidermis in IEN type IGAP $(3,16)$. In the upper dermis, a superficial perivascular and interstitial infiltrates of lymphocytes, neutrophils and sometimes eosinophils are present (19). 


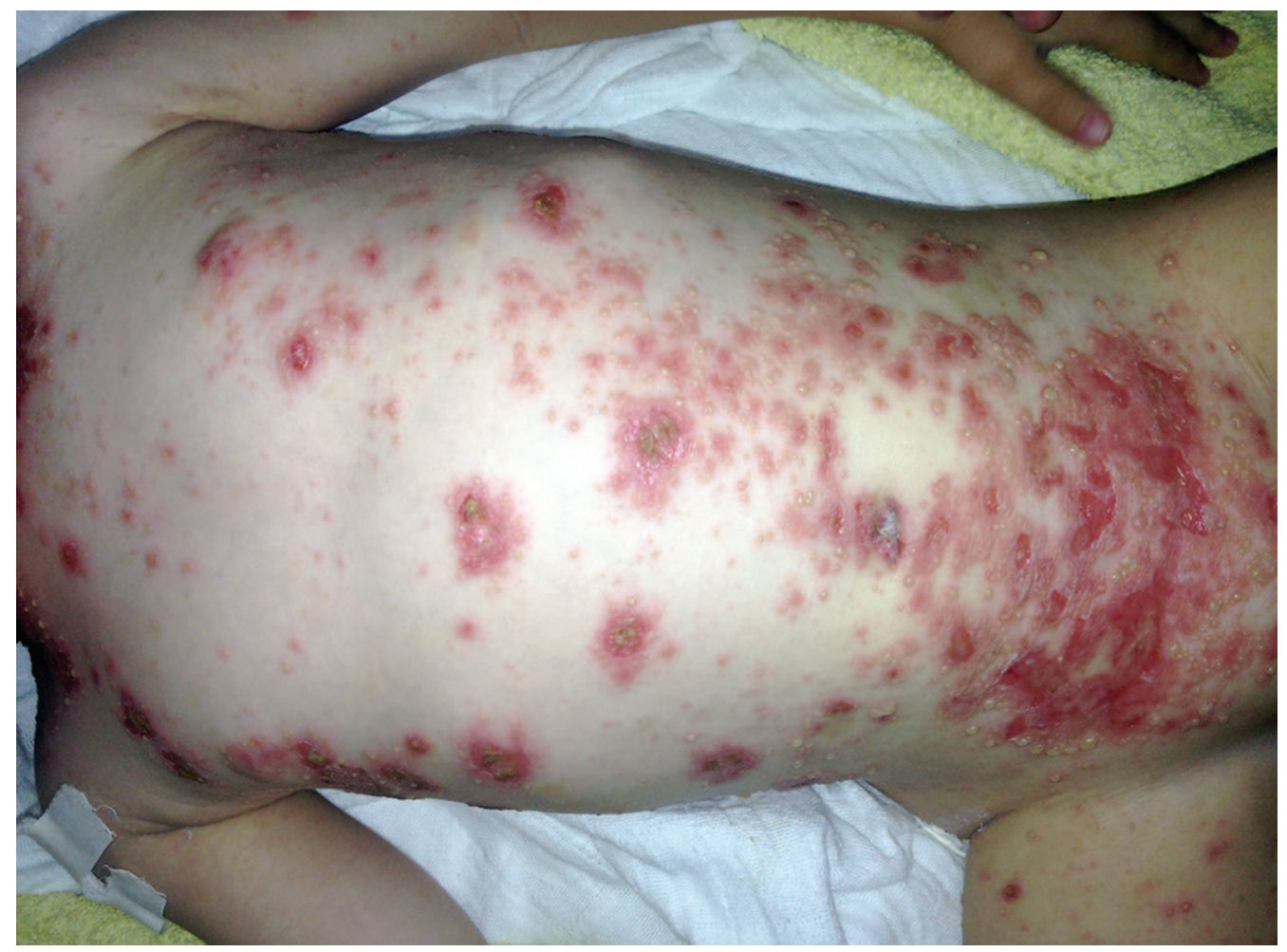

Figure 2. Pustules, superficial erosions and erythematous plaques on the trunk

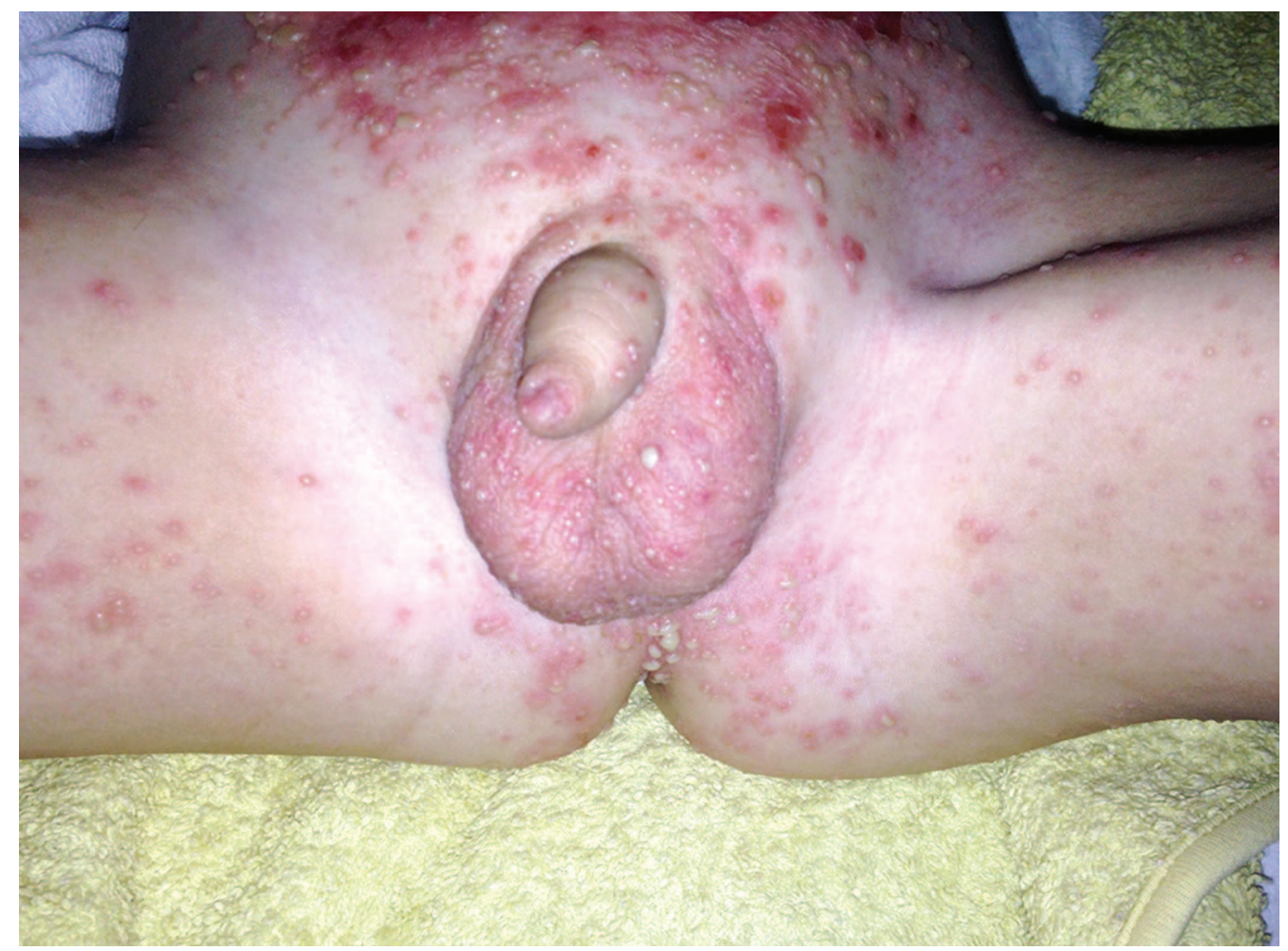

Figure 3. Vesicles, pustules and erythema in the groin area 
Desmocollin 1 (Dsc1) has recently been identified as the target antigen of the SPD type (15). In the IEN type, no reactivity of autoantibodies with Dsc 1, 2, and 3 has been found, whereas desmoglein 1 and 3 were suggested as putative target antigens of IEN type in single case reports $(20,21)$. Although the autoantigen for IEN type has not been identified, immunoelectron microscopic studies suggest that it is an unknown nondesmosomal protein (22). There is no clear explanation for the mechanism by which IgA autoantibodies produce characteristic skin lesions in IGAP. IgA autoantibodies might bind to the FC receptor CD89 on monocytes and granulocytes, resulting in accumulation of neutrophils and subsequent proteolytic cleavage of the keratinocyte cell-cell junction (3).

The diagnosis can only be confirmed by immunofluorescence examinations. DIF tests using perilesional skin from affected patients were positive in all reported cases and showed deposits of IgA on the surface of keratinocytes. In SPD type, IgA deposition is seen predominantly in the upper epidermal layers, whereas in IEN type, it is seen throughout the epidermis or restricted to the lower epidermis. IgG or complement component C3 is also sometimes deposited, but is weaker than $\lg A(3,5,16,23)$.

In addition to routine cytological tests, Tzanck smears were studied by DIF staining to detect antibodies present on the cell surfaces, as acantholytic cells of pemphigus also bear antigens. The deposition occurs on the cell surface without staining the nucleus (24). The role of DIF techniques on Tzanck smear samples has also been evaluated for the diagnosis of pemphigus vulgaris, and the results were found to be comparable with respective skin biopsies in the same set of patients. Thus, Tzanck smear can be used as a substitute to biopsy (25). In our case, IgA deposits were present on the individual cells and in the intercellular substances where the cells were present in clusters.

IIF tests of the patient's serum on normal human skin, and monkey and guinea-pig esophagus tissue, show binding of IgA autoantibodies with an intercellular pattern. The titers for autoantibodies are much lower than in classic pemphigus $(3,23)$. IIF using monkey esophagus tissue did not detect autoantibod-

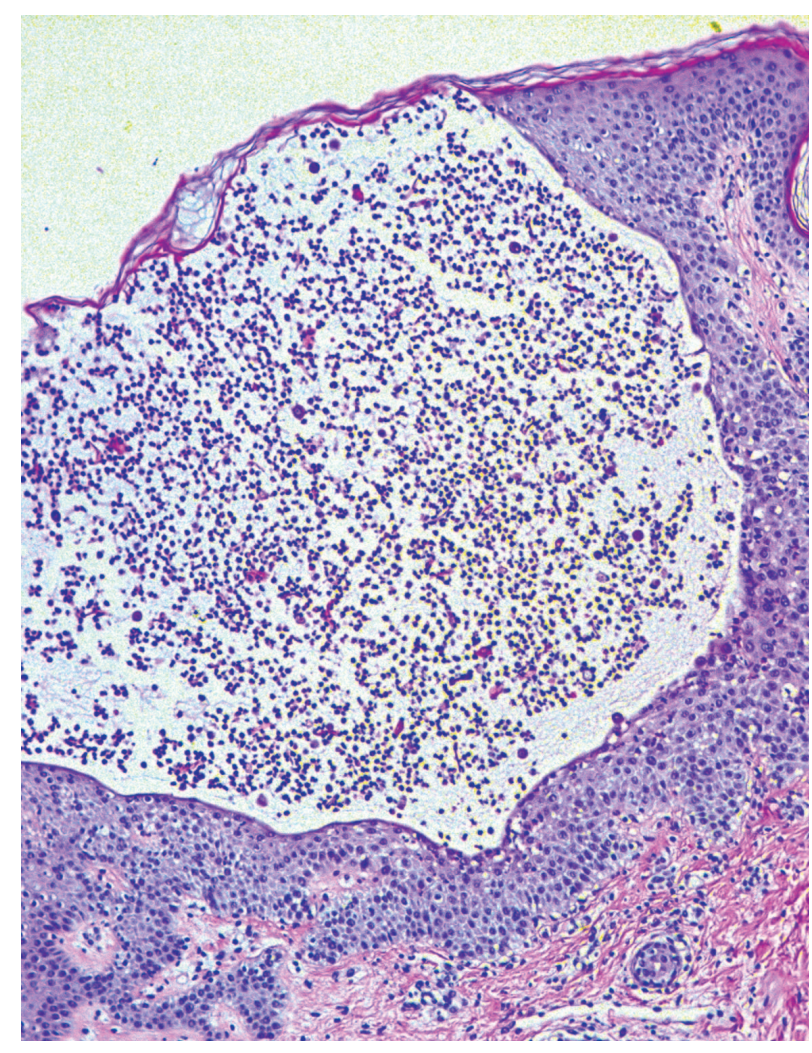

Figure 4. Histopathology of the skin lesion: subcorneal neutrophilic pustules, mild epidermal spongiosis and perivascular and interstitial lymphocytic infiltrate with neutrophils in the upper dermis (HE x 100)

ies in our patient, and it may not be suitable for detection of anti-Dsc1 antibodies, because esophagus expresses undetectable levels of Dsc (26). Since IIF microscopy has a sensitivity of about only $50 \%$ in IGAP, a more sensitive IF molecular assay has been developed using Dsc-transfected COS-7 cells (4). The vectors coding for Dsc1-Dsc3 are individually transfected to COS-7 cells. Then, patient sera are reacted with these transfected cells. Dotted fluorescent signals are obtained at the cell surfaces if patient sera react with such target antigens (3).

Enzyme-linked immunosorbent assay (ELISA) is used for the diagnosis of IGAP and for detection of autoantibodies in individual patients $(16,27)$. The specificity and sensitivity of Dsc and ELISA is not very high compared with immunofluorescence study using Dsc-transfected COS-7 cells $(4,28)$. Immunoblotting using a desmosome-enriched frac- 


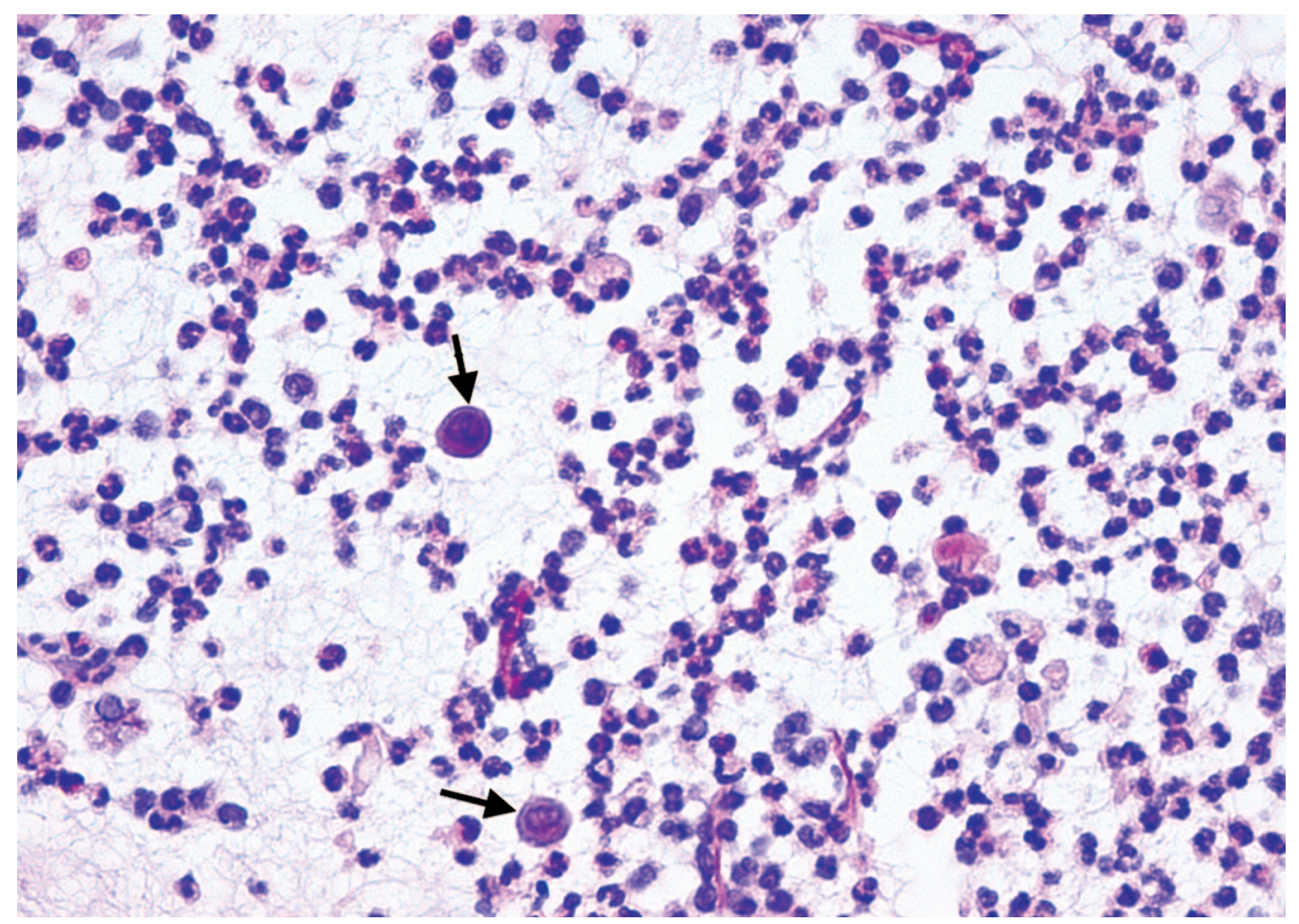

Figure 5. Histopathology of the skin lesion: a few acantholytic cells (black arrows) and numerous neutrophils (HE x 400)

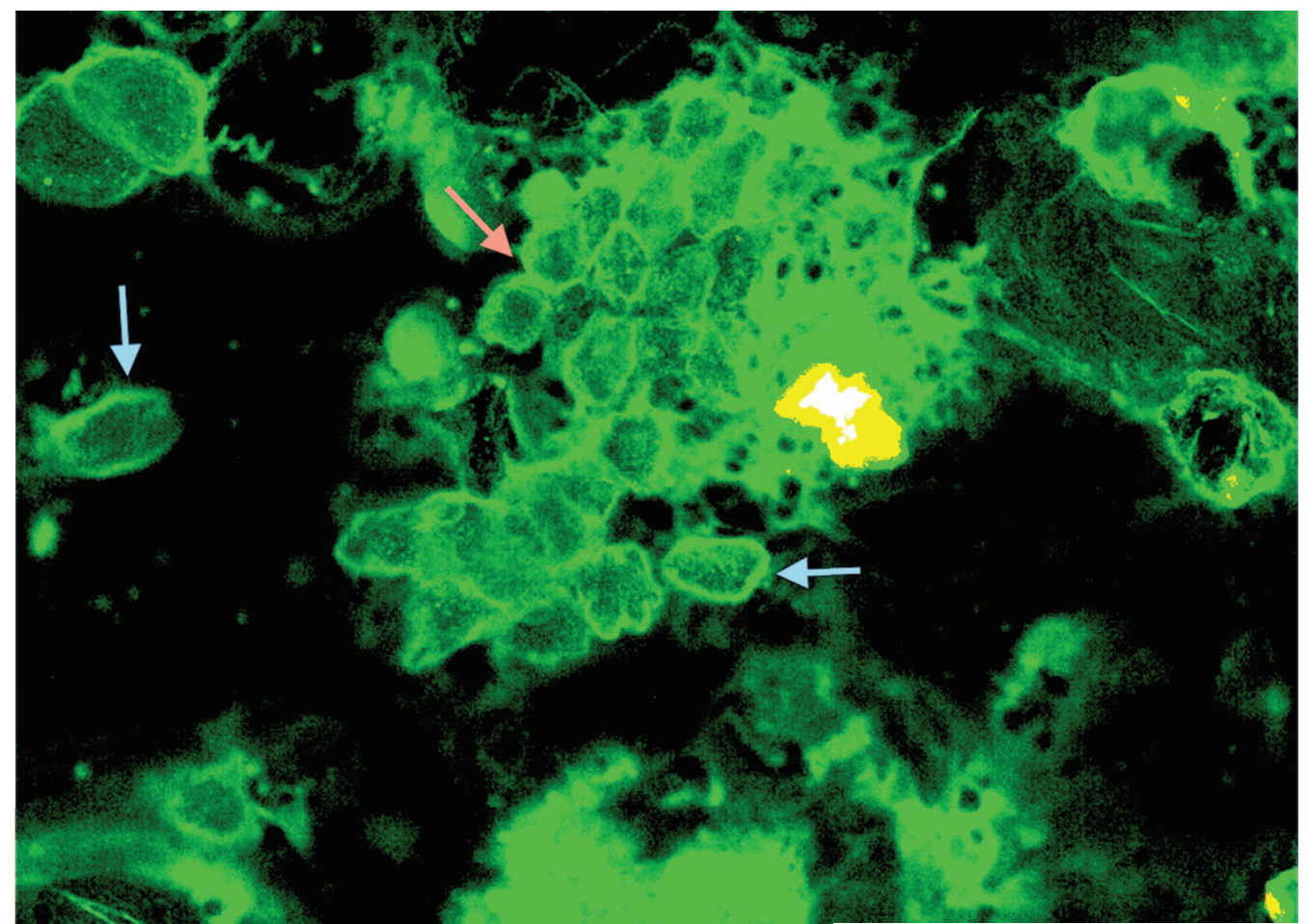

Figure 6. DIF of Tzanck smears $(\operatorname{lgA})$ showing classical distinct regular pericellular membranous ring-shaped deposits on individual acantholytic cells (blue arrows) and those in groups (red arrow) 
tion of a bovine snout epidermal extract can be helpful to detect IgA autoantibodies against Dsc, although the sensitivity is similarly low (4).

Monoclonal IgA gammopathy (benign or malignant) was present in $20 \%$ of cases with SPD type. In cases associated with malignant IgA gammopathy, the prognosis depends on the malignancy. In the IEN type, no association with monoclonal IgA gammopathy has been reported (15). Gastrointestinal disease may also be associated with IGAP. One case of Crohn's disease and one with gluten-sensitive enteropathy have been reported in the literature (29).

The treatment of choice for both types of IGAP is dapsone (18). If dapsone is not well tolerated, sulphapyridine in combination with prednisone or photochemotherapy with psoralen-ultraviolet $A$, alone or in combination with etretinate are usual alternatives $(14,29)$. Other reported therapeutic agents include colchicine (30), isotretinoin (31), acitretin (32), azathioprine (33), azithromycin (34), mycophenolate mofetil, adalimumab (35), plasmapheresis and cyclophosphamide (17) and various combinations of these treatments. The overall prognosis in children with IGAP seems to be good and the disease can be easily controlled by a combination of low dose steroids and dapsone $(5,7)$.

\section{Conclusion}

Autoimmune blistering diseases are rare in the pediatric patients. Our patient represents a very rare pediatric case with SPD type IGAP. The presence of acantholytic cells in cytology and IgA deposition on acantholytic cells found using DIF would make the Tzanck test more specific and very useful in the diagnosis of IGAP. The DIF of Tzanck smear is a simple, sensitive, rapid and non-aggressive test, very suitable for the diagnosis of IGAP in children.

\section{Abbreviations}

IGAP - immunoglobulin A pemphigus

SPD - subcorneal pustular dermatosis

IEN - intraepidermal neutrophilic

DIF - direct immunofluorescence

IIF - indirect immunofluorescence
Dsc1 - desmocollin 1

ELISA - enzyme-linked immunosorbent assay

\section{References}

1. Męcińska-Jundziłł K, Hashimoto T, Kowalewski C, Woźniak K, Ishii N, Czajkowski R. Discrepancies among clinical, histological and immunological findings in lgA pemphigus: a case report and literature survey. Postepy Dermatol Alergol. 2016;33(6):480-4.

2. Geller S, Gat A, Zeeli T, Hafner A, Eming R, Hertl M, et al. The expanding spectrum of IgA pemphigus: a case report and review of the literature. $\mathrm{Br} \mathrm{J}$ Dermatol. 2014;171(3):650-6.

3. Tsuruta D, Ishii N, Hamada T, Ohyama B, Fukuda S, Koga $\mathrm{H}$, et al. IgA pemphigus. Clin Dermatol. 2011;29(4):437-42.

4. Otten JV, Hashimoto T, Hertl M, Payne AS, Sitaru C. Molecular diagnosis in autoimmune skin blistering conditions. Curr Mol Med. 2014;14(1):69-95.

5. Neethu KC, Rao R, Balachandran C, Pai S. Juvenile IgA pemphigus: a case report and review of literature. Indian J Dermatol Venereol Leprol. 2016;82(4):439-42.

6. de Oliveira JP, Gabbi TV, Hashimoto T, Aoki V, Santi CG, Maruta CW, et al. Two Brazilian cases of IgA pemphigus. J Dermatol. 2003;30(12):886-91.

7. Caputo R, Pistritto G, Gianni E, Carminati G, Crupi $A$, Berti $E$, et al. IgA pemphigus in a child. J Am Acad Dermatol. 1991;25(2 Pt 2):383-6.

8. Bruckner AL, Fitzpatrick JE, Hashimoto T, Weston WL, Morelli JG. Atypical IgA/lgG pemphigus involving the skin, oral mucosa, and colon in a child: a novel variant of IgA pemphigus? Pediatr Dermatol. 2005;22(4):321-7.

9. Suzuki M, Karube S, Kobori Y, Usui K, Murata S, Kato $\mathrm{H}$, et al. IgA pemphigus occurring in a 1-monthold infant. J Am Acad Dermatol. 2003;48(2 Suppl):S22-4.

10. Weston WL, Friednash M, Hashimoto $T$, Seline $P$, Huff JC, Morelli JG. A novel childhoood pemphigus vegetans variant of intraepidermal neutrophilic lgA dermatosis. J Am Acad Dermatol. 1998;38(4):635-8.

11. Saurat JH, Merot Y, Salomon D, Didierjean L. Pemphigus-like IgA deposits and vesiculo-pustular dermatosis in a 10-year-old girl. Dermatology. 1987; 175:96-100.

12. Gooptu C, Mendelsohn S, Amagai M, Hashimoto T, Nishikawa T, Wojnarowska F. Unique immunobullous disease in a child with a predominantly IgA response to three desmosomal proteins. $\mathrm{Br} \mathrm{J}$ Dermatol. 1999;141(5):882-6.

13. Teraki Y, Amagai N, Hashimoto T, Kusunoki T, Nishikawa T. Intercellular IgA dermatosis of childhood. Selective deposition of monomer IgA1 in the 
intercellular space of the epidermis. Arch Dermatol. 1991;127(2):221-4.

14. Robinson ND, Hashimoto T, Amagai M, Chan LS. The new pemphigus variants. J Am Acad Dermatol. 1999;40(5 Pt 1): 649-71.

15. Yasuda H, Kobayashi $\mathrm{H}$, Hashimoto $\mathrm{T}$, Itoh K, Yamane M, Nakamura J. Subcorneal pustular dermatosis type of IgA pemphigus: demonstration of autoantibodies to desmocollin-1 and clinical review. Br J Dermatol. 2000;143(1):144-8.

16. Porro AM, Caetano Lde V, Maehara Lde S, Enokihara MM. Non-classical forms of pemphigus: pemphigus herpetiformis, IgA pemphigus, paraneoplastic pemphigus and IgG/IgA pemphigus. An Bras Dermatol. 2014;89(1):96-106.

17. Chorzelski TP, Beutner EH, Kowalewski C, Olszewska M, Maciejowska E, Seferowicz E, et al. IgA pemphigus foliaceus with a clinical presentation of pemphigus herpetiformis. J Am Acad Dermatol. 1991;24(5 Pt 2):839-44.

18. Robinson ND, Hashimoto T, Amagai M, Chan LS. The new pemphigus variants. J Am Acad Dermatol. 1999;40(5 Pt 1):649-71; quiz 672-3.

19. Radoš J. Autoimmune blistering diseases: histo logic meaning. Clin Dermatol. 2011;29(4):377-88.

20. Hegazy S, Bouchouicha S, Khaled A, Laadher L, Sellami MK, Zeglaoui F. IgA pemphigus showing IgA antibodies to desmoglein 1 and 3. Dermatol Pract Concept. 2016;6(4):31-3.

21. Tajima M, Mitsuhashi Y, Irisawa R, Amagai M, Hashimoto T, Tsuboi R. IgA pemphigus reacting exclusively to desmoglein 3. Eur J Dermatol. 2010;20(5):626-9.

22. Ishii N, Ishida-Yamamoto A, Hashimoto T. Immunolocalization of target autoantigens in IgA pemphigus. Clin Exp Dermatol. 2004;29(1):62-6.

23. Shetty VM, Subramaniam K, Rao R. Utility of immunofluorescence in dermatology. Indian Dermatol Online J. 2017;8(1):1-8.

24. Kabir AK, Kamal M, Choudhury AM. Clinicopathological correlation of blistering diseases of skin. Bangladesh Med Res Counc Bull. 2008;34(2):48-53.
25. Chhabra S, Minz RW, Saikia B. Immunofluorescence in dermatology. Indian J Dermatol Venereol Leprol. 2012;78 (6):677-91.

26. King IA, Sullivan KH, Bennett R Jr, Buxton RS. The desmocollins of human foreskin epidermis: identification and ch chromósomal assignment of a third gene and expression patterns of the three isoforms. J Invest Dermatol. 1995; 105(3):314-21.

27. Hashimoto T, Komai A, Futei Y, Nishikawa T, Amagai M. Detection of IgA autoantibodies to desmogleins by an enzyme-linked immunosorbent assay: the presence of new minor subtypes of IgA pemphigus. Arch Dermatol. 2001; 137(6):735-8.

28. Hashimoto T, Yasumoto $S$, Nagata $Y$, Okamoto $T$, Fujita S. Clinical, histop pathological and immunological distinction in two case Clin Exp Dermatol. 2002;27(8):636-40.

29. Wallach D. Intraepidermal IgA pustulosis. J Am Acad Dermatol. 1992;27(6 Pt 1):993-1000.

30. Hodak E, Lapidoth M, David M. Effect of colchicine in the subucorneal pustular dermatosis type of IgA pemphigus. J Am Acad Dermatol. 1999;40(1):91-4.

31. Gruss C, Zillikens D, Hashimoto T, Amagai M, Kroiss $M$, Vogt $T$, et al. Rapid response of IgA pemphigus of subcorneal pustular dermatosis type to treatment with isotretinoin. J Am Acad Dermatol. 2000;43(5 Pt 2):923-6.

32. Ruiz-Genao DP, Hernández-Núñez A, Hashimoto T, Amagai M, Fernández-Herrera J, García-Díez A. A ca ase of IgA pemphigus succe acitretin. Br J Dermatol. 2002;147(5):1040-2.

33. Zillikens D, Miller K, Hartmann AA, Burg G. IgA pemphigus foliaceus: a case report. Dermatologica. 1990;181(4):304-7.

34. Bliziotis I, Rafailidis P, Vergidis P, Falagas ME. Regression of subcorneal pustular dermatosis type of IgA pemphigus lesions with azithromycin. J Infect. 2005;51(2):E31-4.

35. Howell SM, Bessinger GT, Altman CE, Belnap CM. Rapid response of IgA pemphigus of the subcorneal pustular dermatosis subtype to treatment with adalimumab and mycophenolate mofetil. J Am Acad Dermatol. 2005;53 (3):541-3.

\section{IgA pemphigus kod deteta - prikaz slučaja}

\section{Sažetak}

IgA pemfigus (IGAP) je retka autoimunska bulozna dermatoza koju karakterišu IgA depoziti u međućelijskim prostorima epiderma. IGAP se klasifikuje na dva tipa: 1) supkornealnu pustuloznu dermatozu (SPD) i 2) intraepidermalnu neutrofilnu IgA dermatozu. Do sada je u literaturi opisano samo devetoro dece sa IGAP, od toga tri slučaja sa SPD tipom. Prikazujemo slučaj trogodišnjeg dečaka sa SPD tipom IGAP. Na licu, trupu, preponama i ekstremitetima bile su prisutne pruriginozne vezikule, pustule i erozije. Histopatološki nalaz je pokazao supkornealnu pustulu sa nekoliko akantolitičkih ćelija. DIF test Cankovog (Tzanck) razmaza pokazao je međućelijske 
depozite IgA u grupi segregovanih epidermalnih ćelija. Nakon dve nedelje opšte terapije dapsonom i prednizonom pacijent je uveden u remisiju, a nakon 11 meseci terapija je obustavljena. Pacijent je 19 meseci u kompletnoj remisiji bez terapije.
DIF test Cankovog razmaza je jednostavan, senzitivan, brz i neagresivan test, veoma pogodan za dijagnostiku IGAP kod dece.

Ključne reči: Imunoglobulin A; Pemfigus; Predškolsko dete; Znaci i simptomi; Dijagnoza; Citodijagnoza; Kožni testovi; Dapson; Prednizon; Ishod terapije 